Review

\title{
Prebiotic Phosphorylation Reactions on the Early Earth
}

\section{Maheen Gull}

School of Geoscience, University of South Florida, 4202 E Fowler Ave., Tampa, FL 33620, USA; E-Mail: ambermaheen@yahoo.com; Tel.: +1-813-974-8979

Received: 28 May 2014; in revised form: 19 June 2014 / Accepted: 9 July 2014 /

Published: 18 July 2014

\begin{abstract}
Phosphorus (P) is an essential element for life. It occurs in living beings in the form of phosphate, which is ubiquitous in biochemistry, chiefly in the form of C-O-P (carbon, oxygen and phosphorus), C-P, or P-O-P linkages to form life. Within prebiotic chemistry, several key questions concerning phosphorus chemistry have developed: what were the most likely sources of P on the early Earth? How did it become incorporated into the biological world to form the $\mathrm{P}$ compounds that life employs today? Can meteorites be responsible for the delivery of P? What were the most likely solvents on the early Earth and out of those which are favorable for phosphorylation? Or, alternatively, were P compounds most likely produced in relatively dry environments? What were the most suitable temperature conditions for phosphorylation? A route to efficient formation of biological $\mathrm{P}$ compounds is still a question that challenges astrobiologists. This article discusses these important issues related to the origin of biological $\mathrm{P}$ compounds.
\end{abstract}

Keywords: phosphorus; phosphorylation; prebiotic chemistry; mineral catalysis; phosphate esters; meteorites; reduced phosphates; phosphate minerals

\section{Introduction}

The origin of life is a fascinating and still an unresolved issue. Deciphering this issue would have huge scientific, social as well as epistemological implications. Scientists have proposed different scenarios to explain the origin of life but these are still unresolved. There are many problems and questions concerning the origin of life including the synthesis of simple biomolecules such as amino acids, simple sugars, and nitrogen bases etc. Furthermore, how did these molecules react to form complex assortments of biomolecules such as lipids, peptides, nucleosides, nucleotides and their ultimate polymerization to form the complex building blocks of life [1]. 
Another relevant question is the necessary concentration of such molecules and their efficient conversions from their simple precursors. Also, what plausible conditions on the Hadean Earth could generate such molecules, as well as concentrate them, leading to the formation of their corresponding biopolymers. Once the biopolymers formed, the next steps would have been the formation of cellular compartments, the generation of cell membranes, with excellent stability and self-assembly properties and ultimately the storage and safe replication and transfer of genetic information.

One problem regarding the prebiotic chemistry is the "problem of phosphorus and phosphorylation". This review article will highlight the most likely sources of $\mathrm{P}$ on the early Earth, potential prebiotic phosphorylation reactions that have been most promising so far and how minerals (serving as catalysts) could have impacted better phosphorylation reactions on the Hadean Earth. It will explore phosphorylation reactions occurring in different solvents, terrestrial sources of phosphorus, phosphorylation reactions by using different sources of orthophosphate (OP thereafter) (both salts and minerals), with or without condensation agents and catalysts, by using condensed phosphates, photo chemically catalyzed phosphorylation reactions, by dry heating, under wet dry cycles, by the use of both aqueous and non-aqueous solvents, by reduced $\mathrm{P}$ sources and meteorites as sources of phosphorus and some recent developments in the realm of prebiotic $\mathrm{P}$ chemistry (Figure 1).

Figure 1. The chart below shows a generic scheme to show various routes that have been described so far in the prebiotic phosphorylation reactions where; OP stands for orthophosphate and TMP stands for trimetaphosphate.

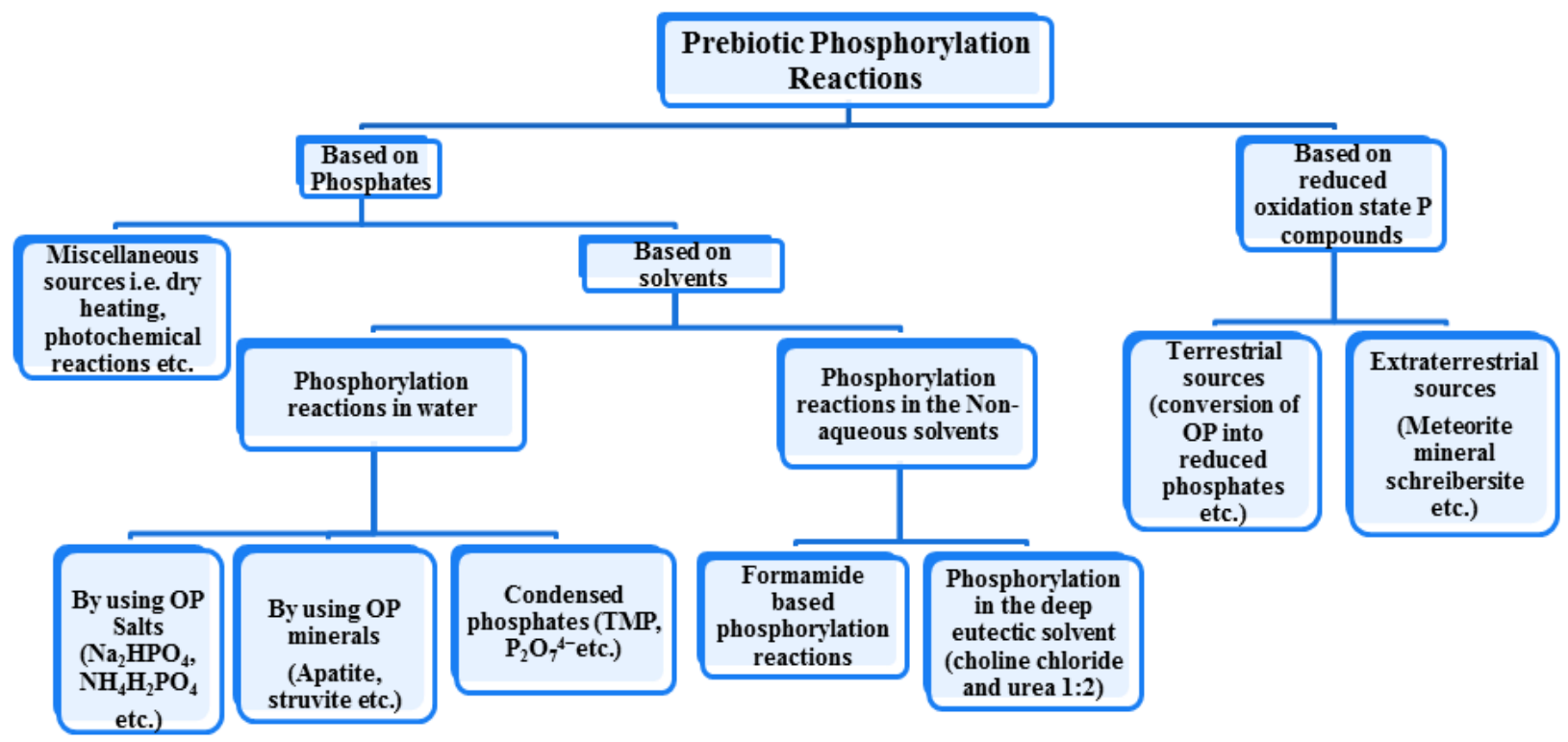

\section{Biological Significance of Phosphorus}

$\mathrm{P}$ is a key biogenic molecule which comprises of about $1 \%$ of the dry weight of cells [2]. It serves in all life properties such as cellular metabolism (cellular respiration, involving sugar phosphates, $\mathrm{P}$ containing enzymes etc.), structure (phospholipids) and a necessary part of information storing molecules (RNA and DNA). Replication and metabolism are the two main biochemical processes that mainly rely on $\mathrm{P}$ as it constitutes $3 \%$ of the atomic composition of RNA, and about $1 \%$ of the atomic composition of the metabolomics [2,3]. Most interestingly, about $44 \%$ of all metabolic compounds 
are biological $\mathrm{P}$ compounds [3]. The phosphorylated biomolecules occurring in living organisms are classified into the following categories; (1) Reactive organophosphates such as acetyl phosphate, phosphoenolpyruvate, phosphocreatine, (2) stable phosphorylated biomolecules such as glycerol phosphates, ribose phosphate, and phosphoethanolamine and (3) condensed phosphates such as adenosine-di-phosphates (ADP), and adenosine-tri-phosphates (ATP) [2].

Biological phosphates containing C-O-P linkages are essential for life (Figure 2). The active participation and significance of $\mathrm{P}$ in the origin of biological compounds and hence life is an old concept dating to Darwin's time. Darwin's thinking about the significance of $\mathrm{P}$ and origin of life can be understood well from his letter written to his close friend Joseph Dalton Hooker: "it is often said that all the conditions for the first production of a living being are now present, which could ever have been present. But if (and oh what a big if) we could conceive in some warm little pond with all sort of ammonia and phosphoric salts, light, heat, electricity present, that a protein compound was chemically formed, ready to undergo still more complex changes" [4]. From other letters to his friends [4], it can be clearly understood that he considered $\mathrm{P}$ as one of the most essential components for the origin of prebiotic biomolecules and how simple materials such as carbonic acid, nitrogenized compounds and phosphorus would have helped in the formation of earlier prebiotic molecules [4].

Figure 2. Some biological phosphates that are vital for cellular activities and hence for life. These include simple sugar phosphates such as glycerol phosphate (for respiration and cell structure) and highly complex molecules such as nucleotides (for storing information), and phospholipids (for structure).

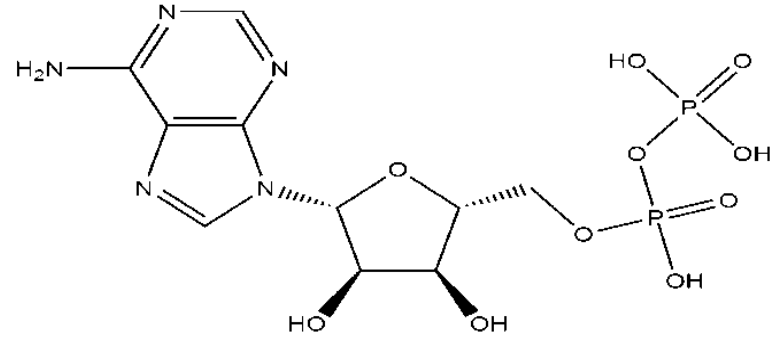

Adenosine-di-phosphate

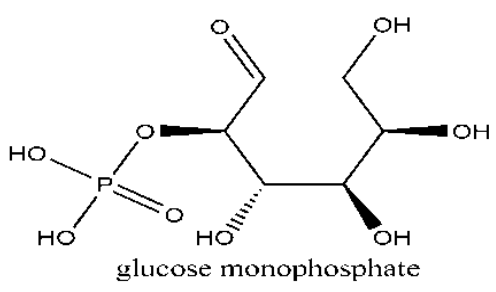

glucose monophosphate
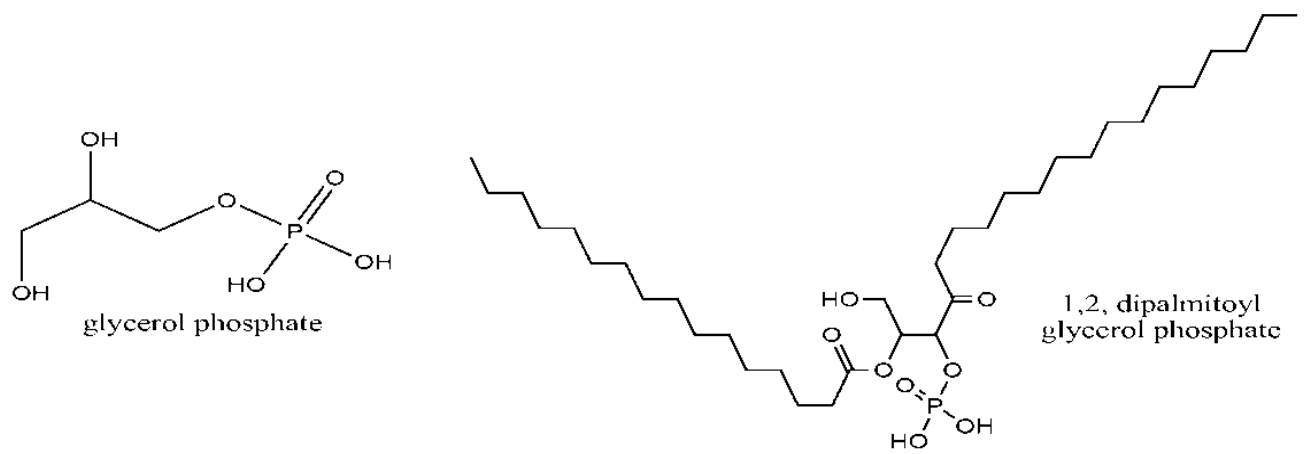

Westheimer describes the significance of $\mathrm{P}$ and $\mathrm{OP}$ and nature's selection of phosphates for multifarious roles in the biochemistry of living beings. Also, in many metabolic reactions the leaving group is usually phosphate or even pyrophosphate [5,6]. Another feature about the significance of 
phosphates links with the fact that living beings must conserve their metabolites within their cell membranes [2,7]. If biomolecules could seep out of their cell membranes during metabolism, these would get diffused into the surrounding water, leaving the cell. Many neutrally charged molecules can easily pass through the cell membranes where organophosphates on the other hand are charged species and hence cannot pass through the cell membranes. Thus, biomolecules can be retained within the cellular boundaries if these are charged species i.e., phosphates [2,5]. In addition, the charge on the phosphates in the DNA and RNA provides greater structural stabilities [2]. One of the most striking features is that the phosphate esters in the DNA and RNA contain negative charges and thus are resistant to hydrolysis and also repel the nucleophiles such as $\mathrm{OH}^{-}$[2].

\section{Phosphorus Minerals and the Origin of Life}

Hazen discusses various forms of $\mathrm{P}$ minerals that may have played a role in the origin of biological phosphate compounds on the early Earth [8]. Primary mineral phases in chondrules of type 3 chondrites include schreibersite, perryite [9] and merrillite [8,10]. The dominant phosphate minerals include apatite $\left(\mathrm{Ca}_{5}\left(\mathrm{PO}_{4}\right)_{3}(\mathrm{~F}, \mathrm{Cl}, \mathrm{OH})\right)$, whitelockite $\left(\mathrm{Ca}_{9}(\mathrm{MgFe})\left(\mathrm{PO}_{4}\right) 6 \mathrm{PO}_{3} \mathrm{OH}\right)$, and brushite $\left(\mathrm{CaHPO}_{4} \cdot 2 \mathrm{H}_{2} \mathrm{O}\right)$ [11]. These minerals are poorly soluble in water and under mild conditions show very little reactivity towards organics [12-15]. Furthermore, on the Hadean Earth the mineral brushite could also have precipitated [16]. Interestingly, it is also assumed that under higher concentrations of $\mathrm{Mg}^{2+}$ and $\mathrm{NH}_{3}$, the mineral struvite $\left(\mathrm{NH}_{4} \mathrm{MgPO}_{4} \cdot 6 \mathrm{H}_{2} \mathrm{O}\right)$ could be formed [16]. However, this possibility is still debatable [17]. An additional possibility is the occurrence of reduced $\mathrm{P}$ compounds and their reactions on the early Earth, and is further discussed in Section 10.

\section{Prebiotic Phosphorylation by Phosphates}

The syntheses of $\mathrm{P}$ compounds of biological relevance have been one of the primary goals of the prebiotic chemistry for the past 50-60 years. One of the primary factors to consider is the suitable solvent. Certainly water being the most ubiquitous solvent in the universe, is the most likely solvent for prebiotic chemistry. Because of the significance of water, finding and tracing water is still the astrobiologists's basic strategy in searching for life in the universe [18] and probable "habitable zones" [19]. This is why most of the significant prebiotic chemistry reactions are primarily attempted in water.

Typically, phosphorylation reaction means a dehydration reaction between an OP and organic molecule. Such a generic reaction is given below;

$$
\mathrm{R}-\mathrm{OH}+\mathrm{HO}-\mathrm{PO}_{3}{ }^{2-} \longrightarrow \mathrm{R}-\mathrm{O}-\mathrm{PO}_{3}{ }^{2-}+\mathrm{H}_{2} \mathrm{O}[2]
$$

The reaction given above is thermodynamically unfavorable. This is because this process is trying to "pull out" water into the aqueous environment, thus making phosphorylation extremely challenging and with low efficiency. This is a major reason why the phosphorylation process has been a challenge in prebiotic chemistry. The major challenging aspects include: a common route to synthesize significant biological P compounds with good yields and with conditions relevant to the Hadean Earth and in the presence of water.

In order to overcome the difficulty of removing water with relative ease, different conditions have been employed such as using condensation agents or other catalysts, heat, attempting better yields by 
using different forms of inorganic $\mathrm{P}$ compounds and even all of the above mentioned factors altogether (Table 1) or the use of potentially prebiotic non-aqueous solvents.

Table 1. Phosphorylation reactions by using OP as phosphate source.

\begin{tabular}{|c|c|c|c|c|c|}
\hline Organic & OP Source & $\begin{array}{c}\text { Reaction } \\
\text { Conditions/Catalysts }\end{array}$ & Products & Yields & Ref. \\
\hline Uridine, thymidine & $\mathrm{NaH}_{2} \mathrm{PO}_{4}$ & $\begin{array}{c}65-95{ }^{\circ} \mathrm{C}, 5-24 \mathrm{~h}, \\
\text { ethylisocyanide }\end{array}$ & $\begin{array}{c}\text { Uridine \& thymidine } \\
\text { phosphates }\end{array}$ & $12 \%$ & [20] \\
\hline D-ribose & Sodium phosphate & $\begin{array}{c}25^{\circ} \mathrm{C}, 21-72 \mathrm{~h}, \\
\text { cyanogen }\end{array}$ & $\begin{array}{c}\text { Ribofuranose } \\
\text { phosphate }\end{array}$ & $6 \%-8 \%$ & [21] \\
\hline $\begin{array}{l}\text { Glucose-1- } \mathrm{PO}_{4} \text { or } \\
\text { glucose-6- } \mathrm{PO}_{4}\end{array}$ & $\begin{array}{l}\mathrm{Na}_{2} \mathrm{HPO}_{4} / \text { with or } \\
\text { without }\end{array}$ & $\begin{array}{l}\text { Room temperature, } \\
2 \mathrm{~h} \text {, cyanogen }\end{array}$ & $\begin{array}{c}\text { Glucose-1, } \\
\text { 6-di-Phosphates }\end{array}$ & $1 \%-3 \%$ & [22] \\
\hline Fructose & $\mathrm{Na}_{2} \mathrm{HPO}_{4}$ & $\begin{array}{l}\text { Room temperature, } \\
2 \mathrm{~h} \text {, cyanogen }\end{array}$ & Fructose Phosphates & $15 \%$ & {$[23]$} \\
\hline Thymidine & Apatite & $\begin{array}{c}90^{\circ} \mathrm{C}, 1 \text { week, } \\
\text { heating leading to } \\
\text { dryness, ammonium } \\
\text { oxalate, cyanides }\end{array}$ & $\begin{array}{l}\text { Thymidine } \\
\text { Phosphates }\end{array}$ & $10 \%-83 \%$ & [24] \\
\hline Uridine & $\begin{array}{c}\mathrm{Na}_{2} \mathrm{HPO}_{4}, \mathrm{Ca}\left(\mathrm{HPO}_{4}\right)_{2} \\
\mathrm{NaH}_{2} \mathrm{PO}_{4}\end{array}$ & $160^{\circ} \mathrm{C}$ & Uridine Phosphates & $0 \%-16 \%$ & {$[25]$} \\
\hline Thymidine & $\mathrm{Na}_{2} \mathrm{HPO}_{4}$ & $65^{\circ} \mathrm{C}$, urea & $\begin{array}{l}\text { Thymidine } \\
\text { Phosphates }\end{array}$ & $25 \%$ & [26] \\
\hline Adenosine & $\left(\mathrm{NH}_{4}\right)_{2} \mathrm{HPO}_{4}, \mathrm{KH}_{2} \mathrm{PO}_{4}$ & $\begin{array}{c}\text { Electric discharge, } \\
\text { cyanate }\end{array}$ & $\begin{array}{l}\text { Adenosine } \\
\text { Phosphates }\end{array}$ & $2 \%$ & {$[27,28]$} \\
\hline Nucleosides & $\mathrm{Na}_{2} \mathrm{HPO}_{4}$ & $100^{\circ} \mathrm{C}$, urea & $\begin{array}{l}\text { Nucleoside } \\
\text { Phosphates }\end{array}$ & $18 \%$ & [29] \\
\hline Glucose & $\mathrm{H}_{3} \mathrm{PO}_{4}$ & $\begin{array}{c}\text { Room temperature, } \\
\text { dicyanamide }\end{array}$ & Glucose Phosphate & $1.9 \%$ & [30] \\
\hline Uridine & $\mathrm{Ca}_{3}\left(\mathrm{PO}_{4}\right)_{2}$ & $85^{\circ} \mathrm{C}$, urea & Uridine Phosphates & $30 \%-80 \%$ & {$[16]$} \\
\hline Trehalose & $\mathrm{NaH}_{2} \mathrm{PO}_{4}$ & $56{ }^{\circ} \mathrm{C}$ & Trehalose Phosphates & $15 \%$ & {$[31]$} \\
\hline Glycerol & $\mathrm{NH}_{4} \mathrm{H}_{2} \mathrm{PO}_{4}$ & $85^{\circ} \mathrm{C}$, urea & Gycerol Phosphates & $30 \%$ & {$[32]$} \\
\hline $\begin{array}{l}\text { Thymidine and } \\
\text { Uridine }\end{array}$ & $\mathrm{NH}_{4} \mathrm{H}_{2} \mathrm{PO}_{4}$ & $100^{\circ} \mathrm{C}$, urea & $\begin{array}{l}\text { Thymidine and } \\
\text { Uridine Phosphates }\end{array}$ & $33 \%$ & {$[33]$} \\
\hline $\begin{array}{c}\text { Choline Chloride, } \\
\text { Glycerol }\end{array}$ & Struvite, monetite & $75-85^{\circ} \mathrm{C}$ & $\begin{array}{c}\text { Choline and Glycerol } \\
\text { Phosphates }\end{array}$ & $3 \%-30 \%$ & {$[17]$} \\
\hline Uridine & $\begin{array}{c}\text { Various OP } \\
\left(\mathrm{H}_{3} \mathrm{PO}_{4}, \mathrm{NaH}_{2} \mathrm{PO}_{4} .\right. \\
2 \mathrm{H}_{2} \mathrm{O}, \mathrm{Na}_{2} \mathrm{HPO}_{4} . \\
7 \mathrm{H} 2 \mathrm{O}, \mathrm{NH}_{4} \mathrm{H}_{2} \mathrm{PO}_{4} \\
\left.\mathrm{Ca}_{3}\left(\mathrm{PO}_{4}\right)_{2} \text { etc. }\right)\end{array}$ & $2 \mathrm{~h}, 125-160^{\circ} \mathrm{C}$ & Uridine Phosphates & $0 \%-16 \%$ & {$[34]$} \\
\hline
\end{tabular}

Notes: Table 1 shows different prebiotic phosphorylation reactions carried out only in water as a solvent and with or without condensation agents. Also, this table shows notable prebiotic phosphorylation reactions of aqueous solutions of organics with different sources of OP (orthophosphates) and without any minerals or clays as catalysts.

The use of condensation agents is highly significant in the phosphorylation reactions. Condensation agents help in facile phosphorylation reactions at even relatively lower temperatures and 
with better yields. For example, cyanogen induced phosphorylation of glucose-1-phosphate into glucose 1, 6-di-phosphate occurs at room temperature with yields 1\%-3\% [22]. A noteworthy point here is the successful conversion of glucose-1-phosphate into glucose 1, 6-di-phosphate under mild conditions. The mechanism was clarified by the use of ${ }^{14} \mathrm{C}$ labeled reactions which showed that the glucose-1- phosphate was capable of being converted into di-phosphate and that cyanogen must be responsible for this intermolecular phosphate transfer from one molecule of glucose-1- phosphate towards the carbon-6 of the other glucose-1-phosphate to form the di-phosphate [22]. Extensive work has also been done which shows that urea and inorganic phosphates form an excellent phosphorylation mixture. Efficient phosphorylations of organic compounds such as glycerol and nucleosides occur when urea is used as a condensation agent (Tables 1 and 2).

\section{Clays, Minerals or Salt Catalyzed Prebiotic Phosphorylations by Using OP}

In addition to the above methods, clays and inorganic compounds have been utilized to synthesize organic-P compounds. Mineral or clay surfaces undergo significant alterations and modifications in the presence of solvents and organics and heat [35-38].

Table 2. Minerals/clays/salts catalyzed phosphorylation reactions by using OP as a source of phosphate.

\begin{tabular}{|c|c|c|c|c|c|}
\hline Organic & OP Source & $\begin{array}{c}\text { Reaction } \\
\text { Conditions/Catalysts }\end{array}$ & Products & Yields & Ref. \\
\hline $\begin{array}{c}\text { Chimyl alcohol *, } \\
\text { dodecanoate }\end{array}$ & $\mathrm{NaH}_{2} \mathrm{PO}_{4}$ & $\begin{array}{l}65^{\circ} \mathrm{C} \text {, cyanamide, } \\
\text { kaolin, silicic acid }\end{array}$ & Phospholipids & $0.015 \%-0.2 \%$ & [39] \\
\hline $\begin{array}{c}\text { Glycerol, } \\
\text { Ethanolamine }\end{array}$ & $\mathrm{H}_{3} \mathrm{PO}_{4}$ & $\begin{array}{l}100-200{ }^{\circ} \mathrm{C} \\
\text { hydrothermal conditions, } \\
\text { minerals }\end{array}$ & $\begin{array}{c}\text { Glycerol and } \\
\text { Ethanolamine } \\
\text { Phosphates }\end{array}$ & $0 \%-1 \%$ & [40] \\
\hline Glucose & $\mathrm{H}_{3} \mathrm{PO}_{4}$ & $\begin{array}{c}100-160{ }^{\circ} \mathrm{C}, \\
\text { hydrothermal conditions, } \\
\text { (kaolinite }+ \\
\text { montmorillonite) }\end{array}$ & Glucose Phosphates & $0.05 \%-2 \%$ & [41] \\
\hline Uridine & $\begin{array}{c}\text { Struvite, } \\
\text { Hydroxylapatite }\end{array}$ & $\begin{array}{c}8-100{ }^{\circ} \mathrm{C}, \text { few hours } \\
1 \text { week, } \mathrm{MgCl}_{2}, \\
\mathrm{NH}_{4} \mathrm{Cl} \text {, urea }\end{array}$ & Uridine Phosphates & $0 \%-39 \%$ & {$[42]$} \\
\hline $\begin{array}{l}\text { Uridine, } \\
\text { Adenosine, } \\
\text { Guanosine, } \\
\text { Thymidine }\end{array}$ & $\begin{array}{c}\mathrm{Na}_{2} \mathrm{HPO}_{4}, \\
\text { Hydroxylapatite } \\
\left(\mathrm{Ca}_{5}\left(\mathrm{PO}_{4}\right)_{3} \mathrm{OH}\right)\end{array}$ & $\begin{array}{c}60-100{ }^{\circ} \mathrm{C}, \mathrm{NH}_{4} \mathrm{Cl} \text {, urea } \\
\mathrm{NH}_{4} \mathrm{HCO}_{3}\end{array}$ & $\begin{array}{l}\text { Uridine phosphates, } \\
\text { Adenosine phosphates, } \\
\text { Guanosine phosphates, } \\
\text { Thymidine phosphates }\end{array}$ & $3 \%-95 \%$ & {$[43]$} \\
\hline
\end{tabular}

Notes: Table 2 shows different prebiotic phosphorylation reactions (by using OP) carried out only in water as a solvent, with or without condensation agents and using different minerals, clays and salts as catalysts.

* Chimyl alcohol (Glycerol 1-hexadecyl ether, (+)-3-(hexadecyloxy)-1,2-propanediol) was chosen as a precursor for phospholipids because it was stable under the conditions used and avoided the requirement of large amount of glycerol and fatty acid in the reaction mixture [39]. Furthermore, this compound is of great prebiotic relevance as it is the major component of ether lipids which are common in archaea. 
The Table 2 shows some of the clay/mineral catalyzed phosphorylation reactions. One of the most important of such minerals and clays belongs to the class of silicates [39-41]. Hydrothermal synthesis of glycerol phosphates has been reported at temperatures as high as $200{ }^{\circ} \mathrm{C}$ by the use of a large variety of different minerals and clay minerals such as garnet, quartz, perlite, kaolinite etc. and iron oxides such as hematite [40]. The maximum yield of the glycerol phosphates was $1 \%$. Under similar conditions a mixture of kaolin and montmorillonite gives detectable yields of glucose mono and di-phosphates which are below detection limits without the clay mixture [41]. Furthermore, it has been found that glycolaldehyde phosphate once sorbed from a weakly alkaline solution into the interlayer of common expanding sheet structure metal hydroxide minerals (i.e., hydrotalcite) condenses into a large range of racemic aldotetrose-2,4-diphosphates and aldohexose-2,4,6-triphosphates [44]. The main reason behind this catalysis is that anionic species such as phosphates, carbonates, ferrocyanides, and phosphate esters usually carry multiple negative charges and are thus efficiently sorbed on in positively charged minerals which leads to interesting polymerization reactions [44]. Another work done on the mixed valence double layer metal hydroxide minerals [45] reports the formation of racemic pentose-2,4-biphosphates by using glycolaldehyde phosphate and glyceraldehyde-2-phosphate as starting materials. The products yield is as high as $48 \%$ [45].

The significance of silicates in the synthesis of nucleotides has also been studied extensively [46] in which the reactivity of adenosine mono-phosphate (AMP), inorganic phosphate adsorbed onto the amorphous silica was studied. Most interestingly, it was found that the inorganic phosphate adsorbed onto the silica condense to polyphosphates at relatively lower temperatures. In addition, in the same temperature range, AMP adsorbed alone undergoes dismutation reactions, giving rise to condensed biological phosphates, such as ADP (adenosine-di-phosphate) and even ATP (adenosine-tri-phosphate). The XRD data of the study showed that there is a competition between the inorganic-phosphate and AMP for surface desorption sites on the silicates [46].

In addition, perhaps one of the earliest methods ever to report the phospholipid synthesis employs the use of silicates as catalysts such as kaolin and silicic acid [39]. Certain ions or their salts such as $\mathrm{Ca}^{2+}$ and $\mathrm{Mg}^{2+}$ are also seen to play important roles in the phosphorylation reactions by dramatically increasing the yield of products containing condensed phosphate [42].

\section{Phospholipid Synthesis by OP}

One of the key methods for the prebiotic syntheses of phospholipids has already been discussed earlier [39] which employs heating chimyl alcohol, dodecanoate, and glycerol in the presence of silicates and condensation agents to produce phospholipids with yields $0.015 \%-0.2 \%$. Another method to report the plausible prebiotic synthesis of phosphatidic acid has been achieved by heating ammonium palmitate, glycerol phosphate, and condensation agents such as cyanimide and imidazole for several hours from $60-90{ }^{\circ} \mathrm{C}$ [47]. The products were monopalmitoyl-glycerol phosphate, monopalmitoyl cyclic-glycerol phosphate, and dipalmitoylglycerol-phosphate with yields from 13\%-60\%. Similarly, heating a mixture of choline chloride, di-sodium phosphatidate, cyanamide, at $80{ }^{\circ} \mathrm{C}$ for a few hours gives complex phospholipid phosphatidylcholine (around 15\%) [48]. 


\section{Photochemical Synthesis Reactions of Biological Phosphates}

Acetyl phosphate, an important biological phosphate, has been synthesized from the photochemical reaction between thioacetic acid and inorganic phosphate while uracil and borax enhanced the overall reactivity of the system [49]. Another photochemical reaction is the synthesis of carbamoyl phosphate from inorganic phosphate and ferricyanide by using visible light [50].

\section{Prebiotic Phosphorylation Reactions by Using Condensed/High Energy Phosphates}

Inorganic OP salts are not known to be effective phosphorylating agents while condensed phosphates or polyphosphates, on the other hand serve as excellent phosphorylating agents [34]. Condensed phosphates or polyphosphates are long chain compounds that are linked together by the removal of water from OP forming a stable P-O-P bond [51]. However, their natural occurrence was not known until the pioneering work of Yamagata and coworkers who demonstrated that volcanic activity can produce water soluble polyphosphates through partial hydrolysis of $\mathrm{P}_{4} \mathrm{O}_{10}$ [52].

Extensive work has been done on prebiotic phosphorylation reactions by using condensed or polyphosphates. Some of the reactions are described in the Table 3 given below.

Table 3. Phosphorylation reactions by using condensed phosphates.

\begin{tabular}{|c|c|c|c|c|c|}
\hline Organic & $\begin{array}{c}\text { Condensed Phosphate } \\
\text { Source }\end{array}$ & $\begin{array}{c}\text { Reaction } \\
\text { Conditions/Catalysts }\end{array}$ & Products & Yields & Ref. \\
\hline Glycolaldehyde & Amidotriphosphate & $\begin{array}{c}\text { Room temp., } 5 \text { days, } \\
\mathrm{Mg}^{2+}\end{array}$ & $\begin{array}{c}\text { Glycolaldehyde } \\
\text { phosphate }\end{array}$ & $76 \%$ & [53] \\
\hline Amino acids & $\begin{array}{c}\text { Trimetaphosphate } \\
\text { (TMP) }\end{array}$ & $\begin{array}{c}35-45^{\circ} \mathrm{C}, 16-40 \mathrm{~h}, \\
\mathrm{pH}=10-11\end{array}$ & $\begin{array}{c}N \text {-phosphor-ylated } \\
\text { amino acids }\end{array}$ & $60 \%-91 \%$ & [54] \\
\hline Glyceric acid & TMP & High pH & Phosphoglyceric acid & $40 \%$ & [55] \\
\hline $\begin{array}{c}\text { Sugars } \\
\text { (glyceraldehyde, } \\
\text { Ribose, Threose, } \\
\text { Erythrose) }\end{array}$ & $\begin{array}{l}\text { Amidotriphosphate or } \\
\text { diamidotriphosphate }\end{array}$ & $\begin{array}{l}4{ }^{\circ} \mathrm{C} \text { room temperature } \\
\qquad \mathrm{MgCl}_{2}\end{array}$ & Sugar phosphates & $25 \%-87 \%$ & {$[56]$} \\
\hline Inosine & Clyclotriphosphate & $\begin{array}{c}\text { High } \mathrm{pH}, \text { room } \\
\text { temperature }-70^{\circ} \mathrm{C}\end{array}$ & Inosine phosphates & $26 \%-33 \%$ & {$[57]$} \\
\hline $\begin{array}{c}\text { Adenosine } \\
\text { monophosphate }\end{array}$ & TMP & $\begin{array}{c}\mathrm{MgCl}_{2}, 100^{\circ} \mathrm{C}, \\
\text { hydrothermal conditions }\end{array}$ & Adenosine phosphates & $1 \%$ & [58] \\
\hline $\begin{array}{l}\text { Beta hydroxyl-n- } \\
\text { alkylamines }\end{array}$ & Cyclic TMP & High $\mathrm{pH}$ & $\begin{array}{l}\text { Beta hydroxyl-n- } \\
\text { alkylamine phosphates }\end{array}$ & $19 \%-40 \%$ & [59] \\
\hline Nucleosides & TMP & High pH & Nucleotides & $50 \%-60 \%$ & [60] \\
\hline Adenosine & Cyclic TMP & $70-85^{\circ} \mathrm{C}, \mathrm{Ni}^{2+}$ & Adenosine phosphates & $30 \%$ & [61] \\
\hline$(\mathrm{AMP})$ & Cyclic TMP & $\mathrm{Mg}^{2+}$ heat & $\begin{array}{c}\text { Adenosine } \\
\text { poly-phosphates }\end{array}$ & $85 \%-90 \%$ & {$[62]$} \\
\hline Adenosine & $\begin{array}{c}\text { Graham's salt, } \\
\mathrm{Na}_{4} \mathrm{P}_{2} \mathrm{O}_{7}, \mathrm{Na}_{5} \mathrm{P}_{3} \mathrm{O}_{10} \text { etc. }\end{array}$ & $\begin{array}{c}\text { Reflux at } 100{ }^{\circ} \mathrm{C}, 4-6 \mathrm{~h}, \\
\text { high } \mathrm{pH}\end{array}$ & Adenosine phosphates & $0 \%-1 \%$ & {$[63]$} \\
\hline Glycolate & TMP & $\begin{array}{l}\text { Near-neutral } \mathrm{pH}, \text { room } \\
\text { temperature, few hours } \\
4 \text { months, Hydrotalcite }\end{array}$ & Phosphoglycolic acid & $34 \%$ & [64] \\
\hline
\end{tabular}

Note: Table 3 shows some phosphorylation reactions by using condensed phosphates as a source of $\mathrm{P}$. 
Table 3 also shows that cyclotrimeta phosphate (cTMP) is one of the most commonly used condensed phosphate in the prebiotic phosphorylation reactions. One interesting reaction is the hydrotalcite catalyzed phosphorylation of glycolate by using TMP at near neutral $\mathrm{pH}$ and ambient temperature [64]. The hydrotalcite member $\left(\mathrm{Mg}_{2} \mathrm{Al}(\mathrm{OH})_{6}\right)(\mathrm{Cl} . \mathrm{nH} 2 \mathrm{O})(n \sim 4)$ of the double layer hydroxide mineral group actively catalyzed the formation of phosphoglycolic acid and the yield was up to $34 \%$ while no phosphorylation products were seen in the absence of hydrotalcite. The study shows that mineral surfaces act as active sites for carrying a variety of catalysis reactions and phosphorylation is one of them.

Another observation here is that these reactions are mostly catalyzed by $\mathrm{Mg}^{2+}$ ion. As it is well known that, $\mathrm{Mg}^{2+}$ ion is essential for the stabilization of the di-phosphate bonds in the ADP [65,66]. The main reason is that $\mathrm{Mg}^{2+}$ ion forms 6-membered rings with the oxygen and phosphorus atom of the ADP and ATP [66].

It is believed that the stable complex formation between $\mathrm{Mg}^{2+}$ ion and oxygen of the $\beta$ - and $\gamma-\mathrm{P}$ parts of the oxyanion in ATP stabilizes the later (Figure 3) [66]. Another study on the role of different metal ions on the formation of nucleotides further proves the significance of $\mathrm{Mg}^{2+}$ ion being able to catalyze the formation of nucleotides approximately 100 times greater than any other catalysts being used in the study [67]. Another example in which $\mathrm{Mg}^{2+}$ ion catalyzes phosphorylation is the successful conversion of glycolaldehyde to glycolaldehyde phosphate (GAP) by using amidotri phosphate [53].

Figure 3. Reprinted and redrawn with permission from [66] shows the probable $\mathrm{Mg}^{2+}$ complexation with ATP. The most common complex is formed with oxygen of the $\beta$ - and $\gamma$-P parts of the oxyanion (Copyright ${ }^{\odot} 2012$ Blackwell Publishing Ltd.).
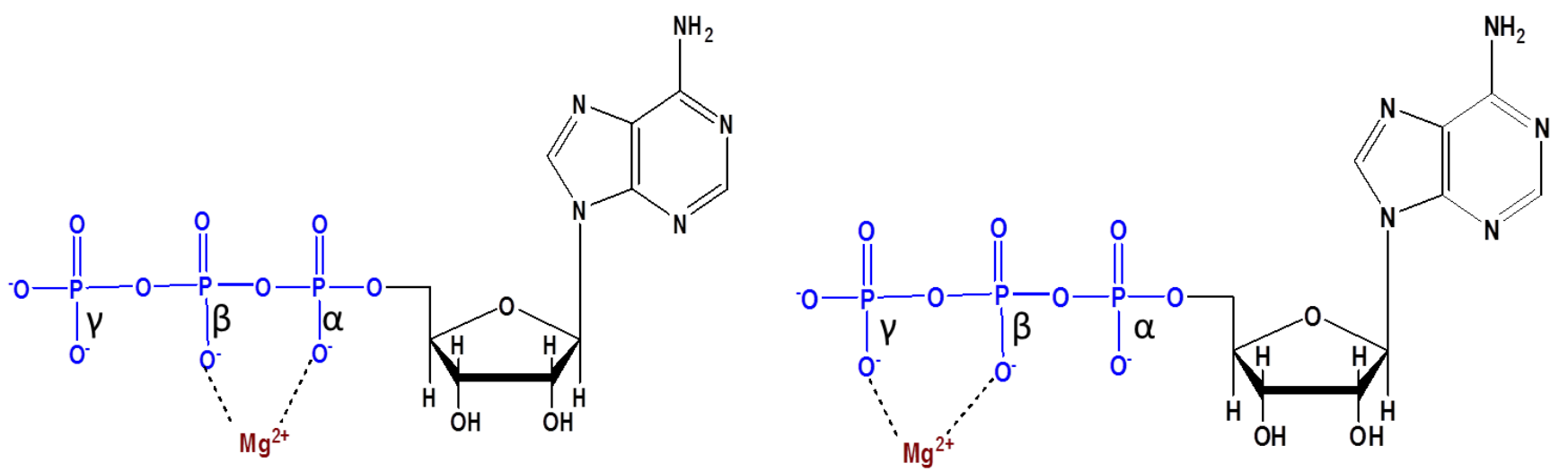

Furthermore, the role of borates in the stability of sugars is worth mentioning which not only stabilizes the sugars but also catalyzes the formation of sugar phosphates (such as ribose phosphate) by forming stable complexes to give better yields of $[68,69]$.

The previous sections discussed the prebiotic phosphorylation reactions in water by using simple OP, condensed phosphates, with or without catalysts and condensation agents. The next section will highlight some of the plausible prebiotic non-aqueous solvents and their scope for prebiotic phosphorylation reactions. 


\section{Prebiotic Phosphorylation Reactions in the Alternative Solvents}

It has been discussed earlier that phosphorylation in water is a challenge [2] and naturally it is extremely challenging to remove water through condensation in the presence of water i.e., "promoting a drying reaction in water". To overcome this challenge, higher temperature is given to a phosphorylation reaction taking place in water as a solvent. This can generate more phosphorylated products as more water is driven off [2]. However, higher temperatures may not only degrade the organic compounds and products but also this may not portray an ideal prebiotic scenario. Furthermore, some of the most prebiotically relevant phosphate minerals such as apatite, whitlockite and rare earth phosphate such as monazite etc. are poorly soluble in water and cannot phosphorylate the organic compounds efficiently. These above mentioned challenges have been overcome by three major routes (1) using condensation agents (such as urea), (2) using reduced oxidation state P compounds (discussed in Section 10) and (3) phosphorylation reactions in prebiotically relevant non-aqueous solvents. This section will highlight some prebiotic phosphorylation reactions that have been attempted in non-aqueous solvents.

One of the most relevant solvents in this context is formamide which is an important prebiotic compound [70], produced prebiotically by irradiation of a mixture of ammonia and carbon monoxide [71,72], as a hydrolysis product of $\mathrm{HCN}$ [73,74], detected as a part of interstellar space [75].

Successful phosphorylation reactions of adenosine and other nucleosides have been reported [70,76-79]. Adenosine phosphorylation in formamide and water as a solvent mixture by using $\mathrm{Na}_{5} \mathrm{P}_{3} \mathrm{O}_{10}$ and heating (in open) at $115^{\circ} \mathrm{C}$ for a few hours was carried out. The process led to the evaporation of water suggesting that water evaporation of primitive ponds containing salts, water, formamide, and other organics might have given rise to the formamide scenario [70,79]. Phosphorylation of nucleosides in this solvent has given a mixed assortment of nucleotides with yields ranging from 6\%-59\% [70,78].

Moreover, the direct release of phosphate from the phosphate minerals in formamide has also been studied by using different phosphate minerals such as; Herderite $\mathrm{Ca}\left(\mathrm{BePO}_{4} \mathrm{~F}\right)$, Hureaulite $\mathrm{Mn}^{2+}{ }_{5}\left(\mathrm{PO}_{3}(\mathrm{OH})_{2}\left(\mathrm{PO}_{4}\right)_{2}\left(\mathrm{H}_{2} \mathrm{O}\right)_{4}\right.$, Libethenite $\mathrm{Cu}^{2+}{ }_{2}\left(\mathrm{PO}_{4}\right)(\mathrm{OH})$, Pyromorphite $\mathrm{Pb}_{5}\left(\mathrm{PO}_{4}\right)_{3} \mathrm{Cl}$, Turquoise $\mathrm{Cu}^{2+} \mathrm{Al}_{6}\left(\mathrm{PO}_{4}\right)_{4}(\mathrm{OH})_{8}(\mathrm{H} 2 \mathrm{O})_{4}$, Fluorapatite $\mathrm{Ca}_{5}\left(\mathrm{PO}_{4}\right)_{3} \mathrm{~F}$, Hydroxylapatite $\mathrm{Ca}_{5}\left(\mathrm{PO}_{4}\right)_{3} \mathrm{OH}$, Vivianite $\mathrm{Fe}^{2+}{ }_{3}\left(\mathrm{PO}_{4}\right)_{2}\left(\mathrm{H}_{2} \mathrm{O}\right)_{8}$, Cornetite $\mathrm{Cu}_{3}^{2+}\left(\mathrm{PO}_{4}\right)(\mathrm{OH})_{3}$, Pseudomalachite $\mathrm{Cu}_{5}^{2+}\left(\mathrm{PO}_{4}\right)_{2}(\mathrm{OH})_{4}$, Reichen-bachite $\mathrm{Cu}_{5}^{2+}\left(\mathrm{PO}_{4}\right)_{2}(\mathrm{OH})_{4}$, and Ludjibaite $\left.\mathrm{Cu}_{5}^{2+}\left(\mathrm{PO}_{4}\right)_{2}(\mathrm{OH})_{4}\right)$ [76]; and phosphorylation of adenosine was also studied by using these phosphate minerals. It was seen that only Libethenite as well as Ludjibaite showed reactivity towards adenosine for phosphorylation and gave up to a few $\%$ phosphorylated adenosine [76]. However, a noteworthy point is the question of the availability of many of these minerals on the early Earth [8].

Recently, another non aqueous solvent, a deep eutectic solvent (urea and choline chloride 2:1) has shown potential towards prebiotic phosphorylation reactions [80]. It is possible that eutectic melts of urea and choline chloride form by heating and drying these mixtures $[81,82]$ and evaporation of water with plausible high concentration of these mixtures with organics, and an inorganic $\mathrm{P}$ source can give rise to an assortment of phosphorylated biomolecules under mild conditions [80].

This method of phosphorylation has phosphorylated a large variety of organics such as nucleosides (adenosine, uridine), alcohols (glycerol, ethanolamine), and sugars such as glucose to form not only mono-phosphates but also the di and tri-phosphates with yields ranging from 10\%-99\%. In addition, choline chloride has also been reported to play dual roles (1) as a component of solvent (2) as an organic 
compound to react with phosphate. This method also produces phosphate esters even when monetite $\left(\mathrm{CaHPO}_{4}\right)$ is used as a phosphate source (Figure 4) [80]. The deep eutectic solvents have proven to have remarkable significance towards biochemistry as well as possible prebiotic scenario [83,84]. It would be justified to consider them as an alternative route to synthesize phosphorylated biomolecules.

Figure 4. It shows ${ }^{31} \mathrm{P}-\mathrm{NMR}$ spectra of different phosphorylation reactions in the deep eutectic solvent (urea and choline chloride 2:1 molar ratio), (a) heating of $\mathrm{Na}-\mathrm{Pi}$ in the DES without the addition of any external organic, indicating the presence of phosphocholine (PC) and orthophosphate (OP), (b) phosphorylation of adenosine with $\mathrm{NaH}_{2} \mathrm{PO}_{4}$, (c) phosphorylation of glycerol by struvite mineral, (d) phosphorylation of uridine with the same mineral (Reprinted with permission from [80]; Copyright ${ }^{\odot} 2013$, Springer Science + Business Media New York).

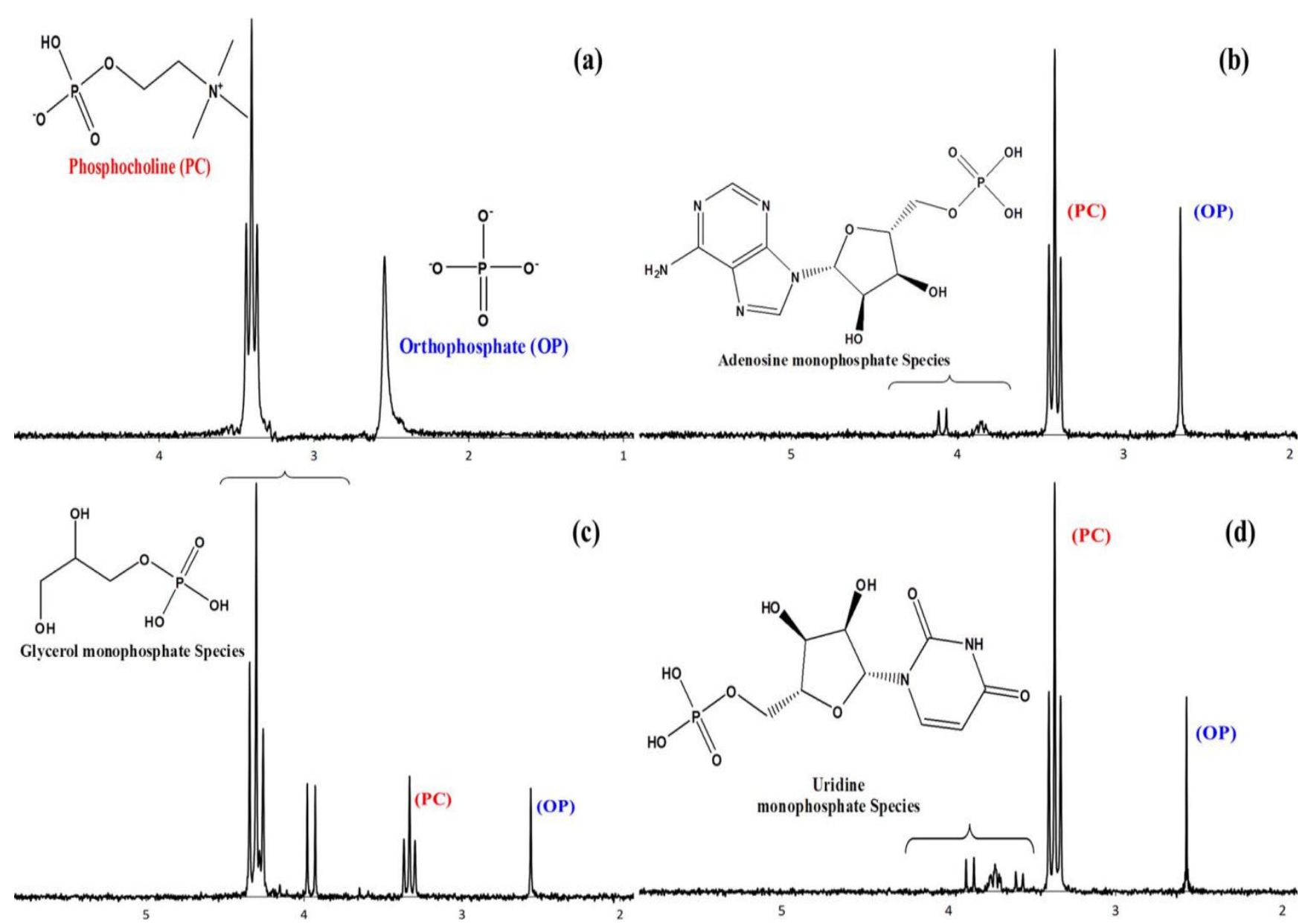

\section{Phosphorylation by Using Reduced Oxidation State Phosphorus Sources}

An alternative route to synthesize phosphate esters are reduced $\mathrm{P}$ compounds, having the charge on $\mathrm{P}$ less than $5^{+}$[2]. Gulick was the first to suggest that such reduced $\mathrm{P}$ compounds might have played a central role in the origin of life due to their increased solubility in water (nearly 1000 times higher than phosphate in water, in the presence of certain divalent cations) [2,13]. The discovery of phosphonic acids in the Murchison meteorite [85] led astrobiologists to consider other alternative forms of $\mathrm{P}$ for the origin of life. Routes to synthesize phosphonic acids by UV irradiation of phosphite, in HCHO 
and simple alcohol's presence have been reported [12,86]. Electric discharges in saturated $\mathrm{N}_{2}$ reduce phosphate to phosphites [87] and successful reduction of $\mathrm{Na}_{2} \mathrm{HPO}_{4}$, hydroxyapatite and fluorapatite with yields ranging from $0.5 \%-11 \%$ [88] show a great potential of reduced oxidation state phosphorus compounds for the prebiotic phosphorylation reactions from another perspective.

Also, nucleoside reaction with $\left.\left(\mathrm{NH}_{4}\right)_{2} \mathrm{HPO}_{3}\right)$ at $60{ }^{\circ} \mathrm{C}$ produces $0 \%-44 \%$ nucleoside phosphonates showing an increased reactivity as compared with the corresponding ammonium phosphate [89].

A relatively recent finding regarding the reactivity of reduced $\mathrm{P}$ compounds is the work on meteorite mineral schreibersite $\left(\mathrm{Fe}_{2} \mathrm{Ni}\right) \mathrm{P}$ [90], a commonly found mineral in the iron meteorites [12,90]. In the study, $\mathrm{Fe}_{3} \mathrm{P}$, an analogue of schreibersite corrodes in water containing acetate and gives a large variety of highly water soluble species such as OP, hypophosphate, phosphites, and even organic $\mathrm{P}$ compounds such as cyclic organic $\mathrm{P}$, phosphonacetate etc. [90] and this study of using $\mathrm{Fe}_{3} \mathrm{P}$ was extended further [91]. The authors described a series of redox reactions taking place in water containing acetate and $\mathrm{Fe}_{3} \mathrm{P}$ (Figure 5) [90,91].

$$
\begin{gathered}
\mathrm{Fe}_{3} \mathrm{P}+7 \mathrm{H}_{2} \mathrm{O} \longrightarrow \mathrm{Fe}_{3} \mathrm{O}_{4}+\mathrm{H}_{3} \mathrm{PO}_{3}+5_{1 / 2} \mathrm{H}_{2}[90,91] \\
\mathrm{H}_{3} \mathrm{PO}_{3}+\mathrm{H}_{2} \mathrm{O} \mathrm{H}_{3} \mathrm{PO}_{4}+\mathrm{H}_{2}(\mathrm{~g}) \longrightarrow[90,91]
\end{gathered}
$$

Equations (2) and (3) show some of the reaction taking place during the aqueous corrosion of $\mathrm{Fe}_{3} \mathrm{P}$. The reactions are further supported by the anoxic irradiation studies of III CD iron meteorite containing schreibersite in the presence of ethanol and water which gives reactive oxyacid $\mathrm{H}$ - phosphinic acid $\mathrm{H}_{3} \mathrm{PO}_{2}$ [92] and other phosphonates [93].

Another finding shows that H-phosphinic acid and pyruvate react in water to form cyclic $\mathrm{P}$ compounds. The H-phosphinate in the system reacts with pyruvic acid to form a di-insertion product which forms amide linkage with an amine; and this linkage between an amine and carboxylic acid is of great prebiotic relevance [94]. The approximate corrosion rate of $\mathrm{Fe}_{3} \mathrm{P}$ in saline solution is found to be about $0.2 \%$ per week or about $10 \%$ per year [95], suggesting that meteoritic phosphides released reduced $\mathrm{P}$ on geologically short time scales; and a sufficient amount of reduced $\mathrm{P}$ would have been available for the origin of life [94]. Furthermore, such meteoritic $\mathrm{P}$ compounds also give high energy P-O-P type compounds [96].

The recent discovery of occurrence of phosphites in early archean marine carbonates has suggested that phosphites were abundant as dissolved species in the ocean before $3.5 \mathrm{Ga}$ [97] and possibly the primary source of these reduced $\mathrm{P}$ compounds on the early Earth may have been meteorites (i.e., meteorites containing schreibersite). Also, $\mathrm{Fe}_{3} \mathrm{P}$ (as an analogue of schreibersite or a source of reduced $\mathrm{P}$ compounds) reacts with aqueous solution of glycerol in an $\mathrm{N}_{2}$ atmosphere at $65{ }^{\circ} \mathrm{C}$ and within 2-3 days produces not only inorganic species of $\mathrm{P}$ but also membrane making glycerol phosphates with yields $2 \%-5 \%$ [97]. This clearly demonstrates that meteorites would also have played a vital role for the origin of biological P compounds on the early Earth. Another fascinating example is the generation of inorganic polyphosphates from reduced P compounds (Figure 6) which shows a promising future of reduced oxidation $\mathrm{P}$ compounds in understanding the origin of life [15]. 
Figure 5. It shows $\mathrm{C}-\mathrm{O}-\mathrm{P}$ and $\mathrm{C}-\mathrm{P}$ type compounds formed due to $\mathrm{Fe} 3 \mathrm{P}$ corrosion in the aqueous solution containing acetate and other simple organics (Reprinted and redrawn with permission from [91]; Copyright ${ }^{\odot} 2007$ Elsevier Ltd.).
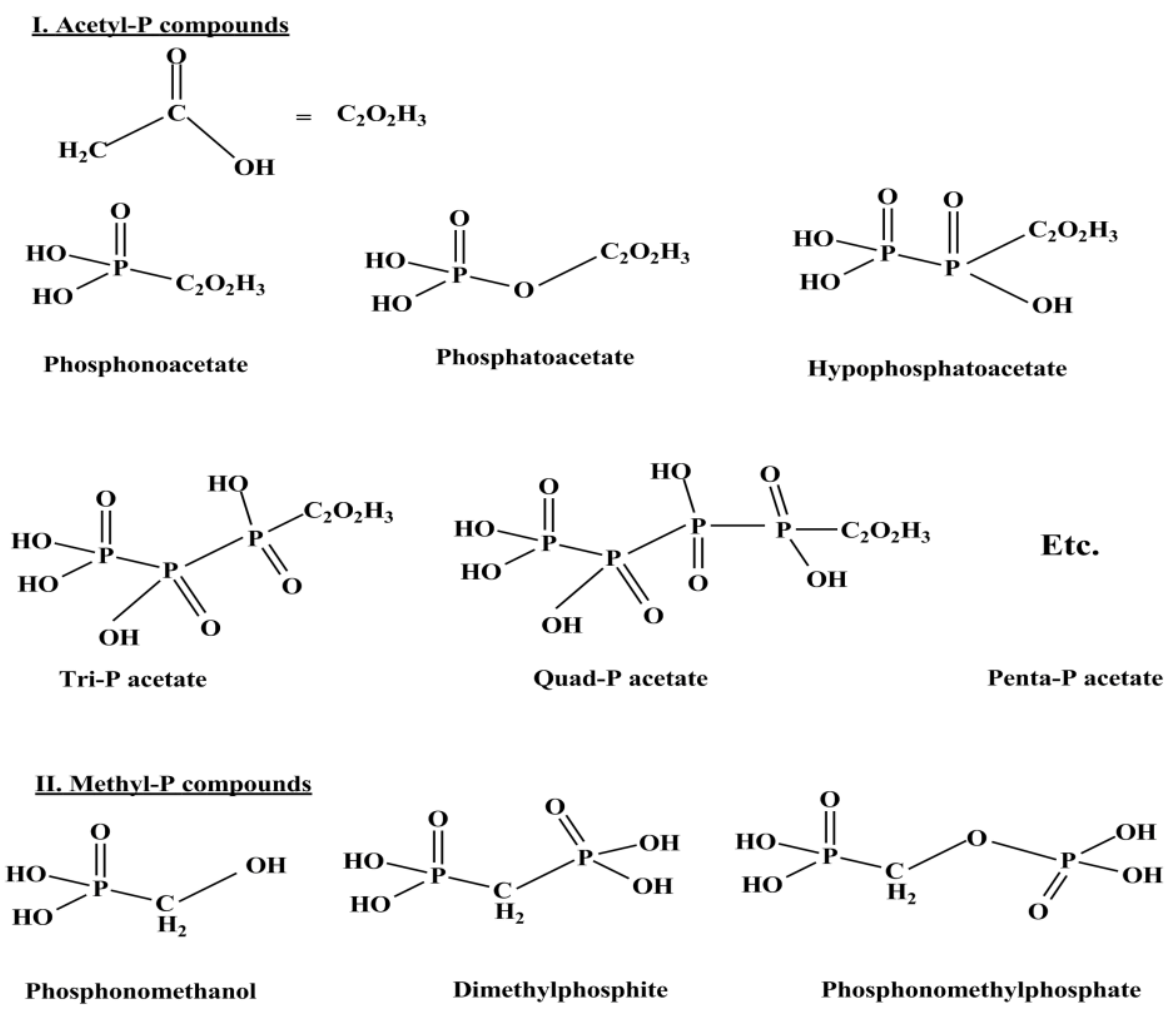

III. Phosphonoformate<smiles>O=C(O)P(=O)(O)O</smiles>

Figure 6. It shows formation of poly-phosphates starting from reduced $\mathrm{P}$ (phosphorus) compounds (Reprinted and redrawn with permission from [15]; Copyright ${ }^{\odot} 2008$ WILEYVCH Verlag GmbH \& Co. KGaA, Weinheim).

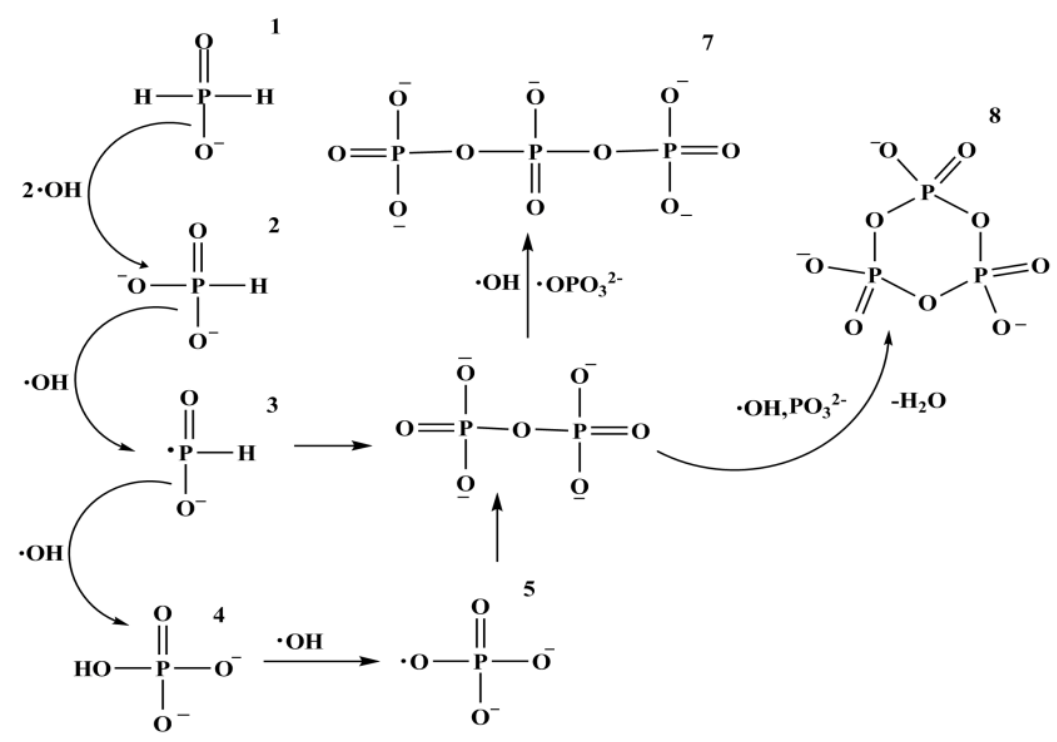




\section{Conclusions and Recapitulations}

As discussed above, there are many possibilities to explore the potential prebiotic phosphorylation reactions by using a variety of $\mathrm{P}$ sources (Figure 7), along with potential prebiotically relevant condensation agents (Figure 8). However, there are some challenges to overcome as well. As discussed earlier, water is the most ubiquitous solvent and a strategy to find life or its possibility anywhere in the universe is to find water [18] but water is a challenge for the phosphorylation reactions and this is why many condensation agents have been employed.

Also, different $\mathrm{pH}$ and temperatures have been employed in different reactions with different catalysts and one of the major challenges is that there are different routes to synthesize different organophosphates and this calls for proposing a single and common route, under similar sets of time, temperature and catalysts to synthesize a large variety of organophosphates.

Figure 7. Shows various forms of phosphates (simple and condensed phosphates) and reduced $\mathrm{P}$ compounds that have been employed in various prebiotic phosphorylation reactions.

1<smiles>O=P([O-])([O-])[O-]</smiles>

Phosphate
2<smiles>O=P([O-])([O-])OP(=O)([O-])[O-]</smiles>

Pyrophosphate
4<smiles>NP(=O)([O-])OP(=O)(O)OP(=O)(O)O</smiles>

Amidotriphosphate
5<smiles>[O-]P([O-])O</smiles>

Phosphite<smiles>O=P1(O)OP(=O)(O)OP(=O)(O)O1</smiles>

Trimetaphosphate
6<smiles>O=P(O)(O)OP([O-])[O-]</smiles>

Pyrophosphite

Figure 8. Shows the most common condensation agents used in the prebiotic phosphorylation reactions.<smiles>NC(N)=O</smiles>

Urea<smiles>N#CN</smiles>

Cyanamide<smiles>N=C=N</smiles>

Carbodiimide<smiles>c1c[nH]cn1</smiles>

Imidazole<smiles>N#CC#N</smiles>

Cyanogen<smiles>N#CNC#N</smiles>

Dicyanamide<smiles>[C-]#[N+]CC</smiles>

$\mathrm{H}_{2}$

Ehylisocyanide 
Another, challenge concerning the prebiotic phosphorylations is the extremely low release of phosphate and inertness by the most prebiotically relevant OP minerals [8] such as apatite, whitlockite and brushite. The status of more efficient OP minerals such as struvite on the early Earth is not clear since they need a high amount of $\mathrm{NH}_{3}$ and $\mathrm{Mg}^{2+}$ to precipitate out $[16,17]$.

Alternative solvents tried so far for phosphorylation reactions have produced good yields of organophosphates and their further potentials are still to be explored [76,80]. Something that is still challenging for prebiotic $\mathrm{P}$ chemistry is the further exploration of the syntheses of phospholipids, studying the membrane formation capabilities by these routes and also the hydrothermal routes that have not been explored much in respect for prebiotic phosphorylation of organics $[40,41,58]$. The main challenge a typical prebiotic phosphorylation reaction in a hydrothermal environment may face will include the rapid decomposition rates of organics.

Recent work on the meteorite mineral schreibersite and its analogue $\mathrm{Fe}_{3} \mathrm{P}$ and the generation of condensed phosphates by Fenton chemistry show a great potential for prebiotic P chemistry [15,95-97] but the next question is the plausible formation of a large variety of organophosphates from such sources.

\section{Acknowledgments}

This work was jointly supported by NSF and the NASA Astrobiology Program, under the NSF Center for Chemical Evolution, CHE-1004570. I sincerely acknowledge Matthew A. Pasek and Virginia Pasek for the wonderful discussions about the manuscript and to Edwin Rivera from USF NMR facility for providing the best NMR facility. Moreover, I am also grateful to the anonymous reviewers for their comments to improve this manuscript. The credit for the colored illustration is given to Nicholas Wagner (A Jepstnp production). Also, I dedicate this article to my beloved mother who has been a continuous source of blessing and to my father who passed away while most of my research work was going on. Thanks are also due to my sisters, Allen Cooke, Drew Barrett and James E. Scholz for helpful discussions about the manuscript.

\section{Conflicts of Interest}

The author declares no conflicts of interest.

\section{References}

1. Ruiz-Mirazo, K.; Briones, C.; de la Escosura, A. Prebiotic systems chemistry: New perspectives for the origins of life. Chem. Rev. 2014, 114, 285-366.

2. Pasek, M.A.; Kee, T.P. On the Origin of phosphorylated biomolecules. In Origins of Life: The Primal Self-Organization; Egel, R., Lankenau, D.-H., Mulkidjanian, A.Y., Eds.; Springer-Verlag: Berlin/Heidelberg, Germany, 2011; pp. 57-84.

3. Srinivasan, V.; Morowitz, H.J. Analysis of the intermediary metabolism of a reductive chemoautotroph. Biol. Bull. 2009, 217, 222-232.

4. Pereto, J.; Bada, J.L.; Lazcano, A. Charles Darwin and the origin of life. Origins Life Evol. Biosphere 2009, 39, 395-406.

5. Westheimer, F.H. Why nature chose phosphate. Science 1987, 235, 1173-1178. 
6. Preiss, J.; Handler, P. Biosynthesis of diphosphopyridine nucleotide. II. Enzymatic aspects. J. Biol. Chem. 1958, 233, 493-500.

7. Davis, R.D. On the importance of being ionized. Arch. Biochem. Biophys. 1958, 78, 497-509.

8. Hazen, R.M.; Papineau, D.; Bleeker, W.; Downs, R.T.; Ferry, J.M.; McCoy, T.J.; Sverjensky, D.A.; Yang, H. Mineral evolution. Amer. Mineral. 2008, 93, 1693-1720.

9. Brearley, A.J.; Jones, R.H. Chondritic meteorites. Rev. Mineral. Geochem. 1998, 36, 1-398.

10. Dove, P.M.; Weiner, S. An overview of biomineralization processes and the problem of the vital effect. Rev. Mineral. Geochem. 2003, 54, 1-29.

11. Arrhenius, G.; Sales, B.; Mojzsis, S.; Lee, T. Entropy and charge in molecular evolution-The case of phosphate. J. Theor. Biol. 1997, 187, 503-522.

12. Schwartz, A.W. Phosphorus in prebiotic chemistry. Phil. Trans. Roy. Soc. B-Biol. Sci. 2006, 361, 1743-1749.

13. Gulick, A. Phosphorus as a factor in the origin of life. Amer. Sci. 1955, 43, 479-489.

14. Gedulin, B.; Arrhenius, G. Sources and geochemical evolution of RNA precursor molecules: The role of phosphate. In Early Life on Earth, Nobel Symposium; Bengston, S., Ed.; Columbia University Press: New York, NY, USA, 1994; Volume 84, pp. 91-110.

15. Pasek, M.A.; Kee, T.P.; Bryant, D.E.; Pavlov, A.A.; Lunine, J.I. Production of potentially prebiotic condensed phosphates by phosphorus redox chemistry. Angew. Chem. Int. Ed. 2008, 47, 7918-7920.

16. Handschuh, G.J.; Orgel, L.E. Struvite and prebiotic phosphorylation. Science 1973, 179, 483-484.

17. Gull, M.; Pasek, M.A. Is struvite a prebiotic mineral? Life 2013, 3, 321-330.

18. Pohorille, A.; Pratt, L.R. Is water the universal solvent for life? Origins Life Evol. Biosphere 2012, 42, 405-409.

19. Kasting, J.F.; Whitmire, D.P.; Reynolds, R.T. Habitable zones around main sequence stars. Icarus 1993, 101, 108-128.

20. Lohrmann, R.; Orgel, L.E. Prebiotic synthesis: Phozsphorylation in aqueous solution. Science 1968, 161, 64-66.

21. Halmann, M.; Sanchez, R.A.; Orgel, L.E. Phosphorylation of D-ribose in aqueous solution. J. Org. Chem. 1969, 34, 3702-3703.

22. Degani, C.; Halmann, M. D-glucose 1-phosphate formation by cyanogen-induced phosphorylation of D-glucose. Synthesis, mechanism, and application to other reducing sugars. J. Chem. Soc. Chem. Commun. 1971, 1459-1465, doi:10.1039/J39710001459.

23. Degani, C.; Kawatsuji, M.; Halmann, M. Cyanogen induced phosphorylation of D-fructose. J. Mol. Evol. 1975, 6, 51-60.

24. Schwartz, A.W.; van-der, V.M.; Bisseling, T.; Chittenden, G.J.F. Prebiotic nucleotide synthesis-Demonstration of a geologically plausible pathway. Origins Life Evol. Biosphere 1975, 6, 163-168.

25. Ponnamperuma, C.; Mack, R. Nucleotide synthesis under possible primitive earth conditions. Science 1965, 148, 1221-1223.

26. Bishop, M.J.; Lohrman, R.; Orgel, L.E. Prebiotic phosphorylation of thymidine at $65{ }^{\circ} \mathrm{C}$ in simulated desert conditions. Nature 1972, 237, 162-164. 
27. Yamagata, Y.; Matsukawa, T.; Mohri, T.; Inomata, K. Phosphorylation of adenosine in aqueous-solution by electric discharges. Nature 1979, 282, 284-286.

28. Yamagata, Y.; Mohri, T.; Yamakoshi, M.; Inomata, K. Constant AMP synthesis in aqueous solution by electric discharges. Origins Life Evol. Biosphere 1981, 11, 233-235.

29. Reimann, R.; Zubay, G. Nucleoside phosphorylation: A feasible step in the prebiotic pathway to RNA. Origins Life Evol. Biosphere 1999, 29, 229-247.

30. Steinmam, G.; Kenyon, D.H.; Calvin, M. Dehydration condensation in aqueous solution. Nature 1965, 206, 707-708.

31. Terelli, E.; Wheeler, S.F. Formation of esters, especially phosphate esters, under "dry" conditions and "mild" pH. Chem. Ind. 1993, 3, 164-165.

32. Epps, D.E.; Nooner, D.W.; Eichberg, J.; Sherwood, E.; Oró, J. Cyanamide mediated synthesis under plausible primitive earth conditions. VI. The synthesis of glycerol and glycerophosphates. J. Mol. Evol. 1979, 14, 235-241.

33. Österberg, R.; Orgel, L.E.; Lohrmann, R. Further studies of urea-catalyzed phosphorylation reactions. J. Mol. Evol. 1973, 2, 231-234.

34. Rabinowitz, J.; Chang, S.; Ponnamperuma, C. Phosphorylation by way of inorganic phosphate as a potential prebiotic process. Nature 1968, 218, 442-443.

35. Hazen, R.M.; Sverjensky, D.A. Mineral surfaces, geochemical complexities, and the origins of life. Cold Spring Harbor Perspect. Biol. 2010, 2, doi:10.1101/cshperspect.a002162.

36. Parks, G.A. Surface energy and adsorption at mineral-water interfaces: An introduction. Rev. Mineral. Geochem. 1990, 23, 133-175.

37. Davis, J.A.; Kent, D.B. Surface complexation modeling in aqueous geochemistry. Rev. Mineral. Geochem. 1990, 23, 177-260.

38. Cappellen, P.V.; Charlet, L.; Stumm, W.; Wersin, P. A surface complexation model of the carbonate mineral-aqueous solution interface. Geochim. Cosmochim. Acta 1993, 57, 3505-3518.

39. Hargreaves, W.R.; Mulvihill, S.J.; Deamer, D.W. Synthesis of phospholipids and membranes in prebiotic conditions. Nature 1977, 266, 78-80.

40. Gull, M.; Ge, T.; Yingwu, W.; Chao, H.; Zhan, S.; Hongming, Y.; Shouhua, F. Resolving the enigma of prebiotic C-O-P bond formation: Prebiotic hydrothermal synthesis of important biological phosphate esters. Heteroat. Chem. 2010, 21, 161-167.

41. Gull, M.; Yu, W.; Yingwu, W.; Zhan, S.; Ge, T.; Shouhua, F. Mimicking the prebiotic acidic hydrothermal environment: One-pot prebiotic hydrothermal synthesis of glucose phosphates. Heteroat. Chem. 2011, 22, 186-191.

42. Handschuh, G.J.; Lohrmann, R.; Orgel, L.E. The effect of $\mathrm{Mg}^{2+}$ and $\mathrm{Ca}^{2+}$ on urea-catalyzed phosphorylation reactions. J. Mol. Evol. 1973, 2, 251-262.

43. Lohrmann, L.; Orgel, L.E. Urea-inorganic phosphate mixtures as prebiotic phosphorylating agents. Science 1971, 171, 490-494.

44. Pitsch, S.; Eschenmose, A.; Gedulin, B.; Hui, S.; Arrhenius, G. Mineral induced formation of sugar phosphates. Orig. Life Evol. Biosph. 1995, 25, 297-334.

45. Krishnamurthy, R.; Pitsch, S.; Arrhenius, G. Mineral induced formation of pentose-2,4-bisphosphates. Origins Life Evol. Biosphere 1999, 29, 139-152. 
46. Thomas, G.; Maguy, J.; Thomas, O.; Aaron-Albert, H.; France, C-T.; Jean-Francois, L. Inorganic phosphate and nucleotides on silica surface: Condensation, dismutation, and phosphorylation. J. Phys. Chem. 2013, 117, 12579-12590.

47. Epps, D.E.; Sherwood, E.; Eichberg, J.; Oró, J. Cyanamide mediated syntheses under plausible primitive earth conditions V. The synthesis of phosphatidic acids. J. Mol. Evol. 1978, 11, 279-292.

48. Rao, M.; Eichberg, J.; Oró, J. Synthesis of Phosphatidylcholine under possible primitive earth conditions. J. Mol. Evol. 1982, 18, 196-202.

49. Hagan, W.J. Uracil-catalyzed synthesis of acetyl phosphate: A photochemical driver for protometabolism. Chem. Biol. Chem. 2010, 11, 383-387.

50. Saygin, O. Nonenzymatic photophosphorylation of acetate by carbamyl phosphate. A model reaction for prebiotic activation of carboxyl groups. Origins Life Evol. Biosphere 1983, 13, 43-48.

51. Brown, M.R.; Kornberg, A. Inorganic polyphosphate in the origin and survival of species. Proc. Natl. Acad. Sci. USA 2004, 101, 16085-16087.

52. Yamagata, Y.; Watanabe, H.; Saitoh, M.; Namba, T. Volcanic production of polyphosphates and its relevance to prebiotic evolution. Nature 1991, 352, 516-519.

53. Krishnamurthy, R.; Arrhenius, G.; Eschenmoser, A. Formation of glycolaldehyde phosphate from glycolaldehyde in aqueous solution. Orig. Life Evol. Biosph. 1999, 29, 333-354.

54. Feng, N.; Shuting, S.; Chao, H.; Yufen, Zhao. N-phosphorylation of amino acids by using trimetaphosphate. Sphate in aqueous solution-learning from prebiotic synthesis. Green Chem. 2009, 11, 569-573.

55. Kolb, V.; Orgel, L.E. Phosphorylation of glyceric acid in aqueous solution using trimetaphosphate. Origins Life Evol. Biosphere 1996, 26, 7-13.

56. Krishnamurthy, R.; Guntha, S.; Eschenmoser, A. Regioselective $\alpha$-phosphorylation of aldoses in aqueous solution. Angew. Chem. Int. Ed. 2000, 39, 2281-2285.

57. Mitsutomo, T.; Mayumi, F.; Shigeru, O. Phosphorylation of inosine with cyclo-triphosphate. Chem. Lett. 1981, 1981, 849-852.

58. Ozawa, K.; Nemoto, A.; Imai, E-I.; Honda, H.; Hatori, K.; Matsuno, K. Phosphorylation of nucleotide molecules in hydrothermal environments. Origins Life Evol. Biosphere 2004, 34, 465-471.

59. Mullen, L.B.; Sutherland, J.D. Formation of potentially prebiotic amphiphiles by reaction of beta-hydroxy-n-alkylamines with cyclotriphosphate. Angew. Chem. Int. Ed. 2007, 46, 4166-4168.

60. Saffhill, R. Selective phosphorylation of the cis-2',3'-diol of unprotected ribonucleosides with trimetaphosphate in aqueous solution. J. Org. Chem. 1970, 35, 2881-2883.

61. Cheng, C.; Fan, C.; Wan, R.; Tong, C.; Miao, Z.; Chen, J.; Zhao, Y. Phosphorylation of adenosine with trimetaphosphate under simulated prebiotic conditions. Origins Life Evol. Biosphere 2002, 32, 219-224.

62. Lohrmann, R. Formation of nucleoside-5'-phosphoramidates under potentially prebiological conditions. J. Mol. Evol. 1977, 10, 137-154.

63. Schwartz, A.W.; Ponnamperuma, C. Phosphorylation of adenosine with linear polyphosphate salts in aqueous solution. Nature 1968, 218, 443.

64. Kolb, V.; Zhang, S.; Xu, Y.; Arrhenius, G. Mineral induced phosphorylation of glycolate ion-A Metaphor in chemical evolution. Origins Life Evol. Biosphere 1997, 27, 485-503. 
65. Lindh, U. Biological functions of the elements. In Essentials of Medical Geology; Impacts of the Natural Environments on Public Health; Selinus, O., Alloway, B., Centeno, J.A., Finkelman, R.B., Fuge, R., Lindh, U., Smedley, P., Eds.; Elsevier Academic Press: Amsterdam, The Netherlands, 2005; pp. 115-160.

66. Holm, N.G. The significance of Mg in prebiotic Geochemistry. Geobiology 2012, 10, 269-279.

67. Yamagata, Y.; Inoue, H.; Inomata, K. Specific effect of magnesium ion on 2',3'-cyclic AMP synthesis from adenosine and trimeta phosphate in aqueous solution. Origins Life Evol. Biosphere 1995, 25, 47-52.

68. Prieur, B.E. Phosphorylation of ribose in the presence of borate salts. Origins Life Evol. Biosphere 2009, 39, 264-265.

69. Scorei, R. Is boron a prebiotic element? A mini-review of the essentiality of boron for the appearance of life on earth. Origins Life Evol. Biosphere 2012, 42, 3-17.

70. Schoffstall, A.M. Prebiotic phosphorylation of nucleosides in formamide. Origins Life Evol. Biosphere 1976, 7, 399-412.

71. Saladino, R.; Crestini, C.; Pino, S.; Costanzo, G.; Mauro, E.D. Formamide and the origin of life. Phys. Life Rev. 2012, 9, 84-104.

72. Hubbard, J.S.; Voecks, G.E.; Hobby, G.L.; Ferris, J.P.; Williams, E.A.; Nicodem, D.E. Ultraviolet-gas phase and -photocatalytic synthesis from $\mathrm{CO}$ and $\mathrm{NH}_{3}$. J. Mol. Evol. 1975, 5, 223-241.

73. Marsh, J.D.F.; Martin, M.J. The hydrolysis and polymerization of hydrogen cyanide in alkaline solutions. J. Appl. Chem. 1957, 7, 205-209.

74. Sanchez, R.A.; Ferris, J.P.; Orgel, L.E. Studies in prebiotic synthesis. II. Synthesis of purine precursors and amino acids from aqueous hydrogen cyanide. J. Mol. Biol. 1967, 30, 223-253.

75. Solomon, P.M. Interstellar molecules. Phys. Today 1973, 26, 32-40.

76. Costanzo, G.; Saladino, R.; Crestini, C.; Ciciriello, F.; Mauro, E.D. Nucleoside phosphorylation by phosphate minerals. J. Biol. Chem. 2007, 282, 16729-16735.

77. Schoffstall, A.M.; Barto, R.J.; Ramos, D.L. Nucleoside and deoxynucleoside phosphorylation in formamide solutions. Origins Life Evol. Biosphere 1982, 12, 143-151.

78. Schoffstall, A.M.; Laing, E.M. Phosphorylation mechanisms in chemical evolution. Orig. Life Evol. Biosph. 1985, 15, 141-150.

79. Saladino, R.; Botta, G.; Pino, S.; Costanzo, G.; di Mauro, E. Genetics first or metabolism first? The formamide clue. Chem. Soc. Rev. 2012, 41, 5526-5565.

80. Gull, M.; Zhou, M.; Fernández, F.M.; Pasek, M.A. Prebiotic phosphate ester syntheses in a deep eutectic solvent. J. Mol. Evol. 2014, 78, 109-117.

81. Mamajanov, I.; Engelhart, A.E.; Bean, H.D.; Hud, N.V. DNA and RNA in anhydrous media: Duplex, triplex, and g-quadruplex secondary structures in a deep eutectic solvent. Angew. Chem. Int. Ed. 2010, 49, 6310-6314.

82. Austin, S.M.; Waddell, T.G. Prebiotic synthesis of vitamin B6-type compounds. Origins Life Evol. Biosphere 1999, 29, 287-296.

83. Maugeri, Z.; Leitner, W.; de Dominguez, M.P. Chymotrypsin-catalyzed peptide synthesis in deep eutectic solvents. Eur. J. Org. Chem. 2013, 2013, 4223-4228. 
84. Abbott, A.P.; Harris, R.C.; Ryder, K.S.; Agostino, C.D.; Gladden, L.F.; Mantle, M.D. Glycerol eutectics as sustainable solvent systems. Green. Chem. 2011, 13, 82-90.

85. Cooper, G.W.; Onwo, W.M.; Cronin, J.R. Alkyl phosphonic-acids and sulfonic-acids in the Murchison meteorite. Geochim. Cosmochim. Acta 1992, 56, 4109-4115.

86. Graaf, R.M.D.; Visscher, J.; Schwartz, A.W. A plausibly prebiotic synthesis of phosphonic acids. Nature 1995, 378, 474-477.

87. Graaf, R.M.D.; Schwartz, A.W. Reduction and activation of phosphate on the primitive earth. Origins Life Evol. Biosphere 2000, 30, 405-410.

88. Glindemann, D.; Graaf, R.M.D.; Schwartz, A.W. Chemical reduction of phosphate on the primitive Earth. Origins Life Evol. Biosphere 1999, 29, 555-561.

89. Graaf, R.M.D.; Schwartz, A.W. Thermal synthesis of nucleoside H-phosphonates under mild conditions. Origins Life Evol. Biosphere 2005, 35, 1-10.

90. Pasek, M.A.; Lauretta, D.S. Aqueous corrosion of phosphide minerals from iron meteorites: A highly reactive source of prebiotic phosphorus on the surface of the early Earth. Astrobiology 2005, 5, 515-535.

91. Pasek, M.A.; Dworkin, J.P.; Lauretta, D.S. A radical pathway for organic phosphorylation during schreibersite corrosion with implications for the origin of life. Geochim. Cosmochim. Acta 2007, 71, 1721-1736.

92. Bryant, D.E.; Kee, T.P. Direct evidence for the availability of reactive, water soluble phosphorus on the early earth. H-phosphinic acid from the Nantan meteorite. Chem. Commun. 2006, 22, 2344-2346.

93. Gorrell, I.B.; Wang, L.; Marks, A.J.; Bryant, D.E.; Bouillot, F.; Goddard, A.; Heard, D.E.; Kee, T.P. On the origin of Murchison meteorite phosphonates. Implications for prebiotic chemistry. Chem. Commun. 2006, 21, 1643-1645.

94. Bryant, D.E.; Marriott, K.E.R.; Macgregor, S.A.; Kilner, C.; Pasek, M.A.; Kee, T.P. On the prebiotic potential of reduced oxidation state phosphorus: The H-phosphinate-pyruvate system. Chem. Commun. 2010, 46, 3726-3728.

95. Bryant, D.E.; Greenfield, D.; Walshaw, R.D.; Evans, S.M.; Nimmo, A.E.; Smith, C.; Wang, L.; Pasek, M.A.; Kee, T.P. Electrochemical studies of iron meteorites. Phosphorus redox chemistry on the early earth. Int. J. Astrobiol. 2009, 8, 27-36.

96. Kee, T.P.; Bryant, D.E.; Herschy, B.; Marriott, K.E.R.; Cosgrove, N.E.; Pasek, M.A.; Atlas, Z.D.; Cousins, C.R. Phosphate activation via reduced oxidation state phosphorus (P). Mild routes to condensed-P energy currency molecules. Life 2013, 3, 386-402.

97. Pasek, M.A.; Harnmeijer, J.P.; Buick, R.; Gull, M.; Atlas, Z. Evidence for reactive reduced phosphorus species in the early archean ocean. Proc. Natl. Acad. Sci. USA 2013, 110, 10089-10094.

(C) 2014 by the authors; licensee MDPI, Basel, Switzerland. This article is an open access article distributed under the terms and conditions of the Creative Commons Attribution license (http://creativecommons.org/licenses/by/3.0/). 